\begin{tabular}{|l|l|l||}
\hline \multicolumn{2}{|c|}{ PublisherInfo } \\
\hline \hline PublisherName & $:$ & BioMed Central \\
\hline \hline PublisherLocation & $:$ & London \\
\hline \hline PublisherImprintName & $:$ & BioMed Central \\
\hline \hline
\end{tabular}

\title{
Cross-species transfer is last straw
}

\begin{tabular}{|l|l|l||}
\hline \multicolumn{2}{|c|}{ ArticleInfo } \\
\hline \hline ArticleID & $:$ & 4888 \\
\hline \hline ArticleDOI & $:$ & $10.1186 /$ gb-spotlight-20031128-01 \\
\hline \hline ArticleCitationID & $:$ & spotlight-20031128-01 \\
\hline \hline ArticleSequenceNumber & $:$ & 240 \\
\hline \hline ArticleCategory & $:$ & Research news \\
\hline ArticleFirstPage & $:$ & 1 \\
\hline \hline ArticleLastPage & $:$ & 2 \\
\hline \hline & & RegistrationDate : 2003-11-28 \\
ArticleHistory & $:$ & OnlineDate $\quad$ 2003-11-28 \\
\hline \hline ArticleCopyright & $:$ & BioMed Central Ltd2003 \\
\hline \hline ArticleGrants & $:$ & \\
\hline \hline ArticleContext & $:$ & 130594411 \\
\hline \hline
\end{tabular}




\section{Cathy Holding}

Email: cholding@hgmp.mrc.ac.uk

In June 2002, a strain of Staphylococcus aureus, resistant to the last remaining antibiotic against the methicillin-resistant S. aureus (MRSA), was isolated from a dialysis patient in Michigan. The vancomycin-resistant $S$. aureus (VRSA) strain was the subject of genetic analysis by Linda Weigel and colleagues at the Centers for Disease Control and Prevention, and their conclusions are reported in the November 28 Science. The drug resistant strain harbored a $57.9 \mathrm{~kb}$ multiresistance, conjugative plasmid with vancomycin resistance encoded in an integrated mobile genetic element, $\mathrm{Tn} 1546$, first reported in an isolate of Enterococcus faecium, and here identified in a co-isolate of Enterococcus faecalis (Science 2003, 302:1569-1571).

Weigel et al. confirmed the identity as $S$. aureus by sequence analysis of specific genes gyrA and gyr $B$ and rDNA and ruled out contamination with enterococci by the inability to amplify enterococcal ligases by polymerase chain reaction. Pulse field analysis confirmed the VRSA to be type USA100 - the most common type in US hospitals. Minimal inhibitory concentration was determined to be $1024 \mu \mathrm{g} / \mathrm{ml}$ for vancomycin, and resistance to aminoglycosides, $\beta$-lactams, fluoroquinolones, macrolides, rifampin, and tetracycline showed that it had retained its MRSA phenotype. Vancomycin resistance was observed to be conferred by vanA, one of several gene clusters found in Enterococcus faecium. Analysis of plasmids from the VRSA and E. faecalis co-isolates identified two plasmids, 45 and $95 \mathrm{~kb}$ long, and Southern blot analysis revealed a 7.1-kb fragment containing vanA. Filter mating studies identified the resistance plasmid as conjugative. The complete sequence has been placed in GenBank.

"Genetic analyses suggest that the long-anticipated transfer of vancomycin resistance to a methicillinresistant $S$. aureus occurred in vivo by interspecies transfer on $\mathrm{Tn} 1546$ from a co-isolate of Enterococcus faecalis. The VRSA plasmid was transferable to other strains of $S$. aureus, reinforcing concerns of potential widespread resistance to one of the few classes of agents still active against multidrug-resistant S. aureus," conclude the authors.

\section{References}

1. Vancomycin-resistant Staphylococcus aureus: a new model of antibiotic resistance

2. Centers for Disease Control and Prevention, [http://www.cdc.gov/]

3. Science, [http://www.sciencemag.org/]

4. GenBank, [http://www.ncbi.nlm.nih.gov/Genbank/index.html]

This PDF file was created after publication. 